\title{
EFFECT OF LH, FSH AND THEIR ANTISERA ON GESTATION IN THE HAMSTER (MESOCRICETUS AURATUS)
}

\author{
A. JAGANNADHA RAO, H. G. MADHWA RAJ AND N. R. MOUDGAL \\ Endocrinology Laboratory, Biochemistry Department, Indian Institute of Science, \\ Bangalore-12, India
}

(Received 22nd April 1971, accepted 19th May 1971)

\begin{abstract}
Summary. When monospecific and well-characterized antiserum to highly purified ovine LH was administered to pregnant hamsters before Day 4, implantation of the ovum was inhibited. Injection of the antiserum between Days 5 and 11 resulted in termination of pregnancy. These effects were accompanied by a reduction in ovarian weights and luteal degeneration. A combination of progesterone and oestradiol-17 $\beta$ were required for complete reversal of the effects of antiserum on implantation and pregnancy. The antiserum was not effective in terminating pregnancy when administered after Day 11. Injection of antiserum to ovine FsH did not alter the course of gestation. Of the three gonadotrophins (FSH, LH and prolactin) administered, only the FSH-LH combination could postpone parturition. From these observations, it can be concluded that deprivation of LH essentially affects luteal function in the pregnant hamster.
\end{abstract}

\section{INTRODUCTION}

In a recent preliminary communication (Jagannadha Rao, Madhwa Raj \& Moudgal, 1970), we reported on the dependence of the intact pregnant hamster on endogenous LH for maintenance of gestation. Greenwald (1967), using the hypophysectomized pregnant hamster as the experimental animal, observed that a combination of FSH and prolactin maintained gestation. The results of a detailed investigation on the effect of highly specific LH and FSH antisera on the course of gestation in the intact hamster are here reported. Using these inhibitors, an attempt has been made to determine the relative need for pituitary LH and FSH for maintaining gestation.

\section{MATERIALS AND METHODS}

Animals and general procedures

Colony-bred female hamsters, weighing 90 to $120 \mathrm{~g}$, were mated to proven males and the day that spermatozoa were detected in the vagina was taken as Day 1 of pregnancy. In the postimplantation studies, the hamsters were subjected to exploratory laparatomy on Day 6 of pregnancy and only those which 
showed a normal number of implantation sites were used for further experimentation. The animals were maintained in individual cages and fed with pelleted food (Hindustan Lever Ltd, Bombay), water being always available.

The hormones (protein hormones in $16 \%$ gelatin and steroids in refined peanut oil) and antisera were administered by the subcutaneous route. At autopsy, the condition of the uterus and ovaries was noted, the ovaries were dissected out and weighed in a torsion balance to the nearest $0.2 \mathrm{mg}$.

Immunization. Antisera to ovine $\mathrm{LH}$ (both $\mathrm{NIH}$ and $\mathrm{Li}$ preparations) were raised in several adult albino female rabbits according to the method of Moudgal \& Li (1961). The antisera samples were suitably absorbed with $1: 10$ diluted normal sheep serum (NSS) and ovine tissue extracts to remove nonspecific antibodies. The completion of absorption, presence of specific antibodies to LH and the cross-reaction of the antibody with hamster LH (hamster pituitary extracts) were tested by using the Ouchterlony agar gel double diffusion test. The sensitive ${ }^{125}$ I-labelled hormone-binding test (Madhwa Raj \& Moudgal, 1970) was used to confirm the absence of antibodies to pituitary FSH and prolactin in this antiserum. The antibody titre of the various batches of antisera were determined by a quantitative precipitin test.

Antiserum to ovine NIH-FSH was prepared and characterized as described earlier by Jagannadha Rao \& Moudgal (1970). The FSH antiserum was subjected to exhaustive absorption and characterization tests similar to those described for LH above.

\section{Histology}

Tissues were fixed in Bouin's fluid for $24 \mathrm{hr}$, embedded in paraffin wax, sectioned to $10 \mu \mathrm{m}$ thickness and stained with haematoxylin and eosin.

\section{RESULTS}

\section{Characterization of $\mathrm{LH}$ and FSH antisera}

The antisera produced to LH and FSH were shown by several tests to be specific for the respective hormones for which they were raised. The absorbed antiserum to LH did not show any precipitin reaction with either FSH or prolactin in the Ouchterlony agar gel diffusion test. Further, when tested by the sensitive radioactively labelled hormone-binding technique (Madhwa Raj \& Moudgal, 1970), of the three ${ }^{125}$ I-labelled hormones tested-LH, FSH and prolactin-only LH showed a specific binding of $83 \%$. The LH antiserum had approximately 9 to $11 \mathrm{mg}$ of antibody protein $/ \mathrm{ml}$ of serum, as determined by the quantitative precipitin test. As can be seen in Pl. 1, Fig. 1, a partial crossreaction was observed between ovine LH and hamster LH (hamster pituitary extract) in the Ouchterlony test using ovine $\mathrm{LH}$ antiserum. The quantitative precipitin test revealed a 30 to $40 \%$ cross-reaction between ovine LH and hamster pituitary LH (Text-fig. 2).

In order to obtain an antiserum specific for FSH, the crude FsH antiserum had to be absorbed with 1:10 diluted NSS, saline extracts of ovine tissues and finally ovine LH. One $\mathrm{ml}$ of this antiserum could neutralize the biological activity of about $800 \mu \mathrm{g}$ of NIH-FSH S-6 as tested in the HGG augmentation assay carried out 


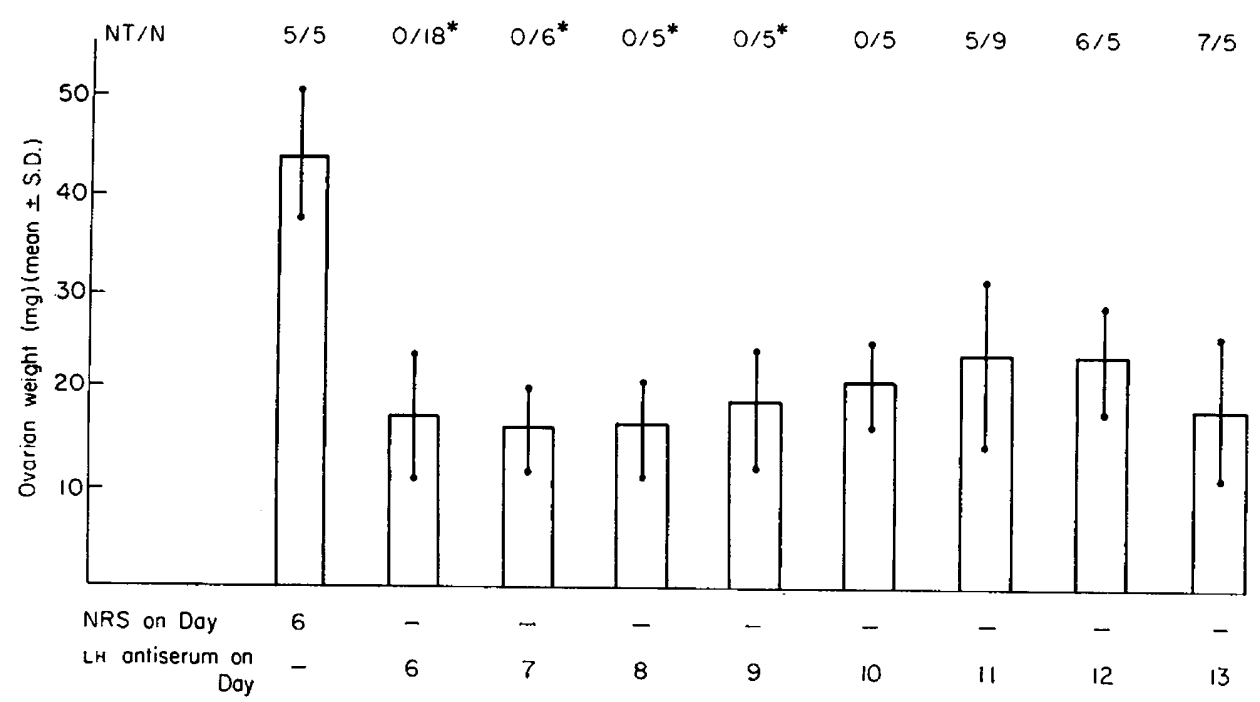

TeXT-FIG. 1. Effect of LH antiserum on pregnancy and ovarian weights in the intact hamster. All animals were subjected to exploratory laparatomy on Day 6. A single injection of $0.2 \mathrm{ml}$ normal rabbit serum (NRS) or LH antiserum was administered by subcutaneous route before 10.00 hours on the day. All animals were killed on Day 16 or 17 except those marked with an asterisk. These were killed on Day 12. NT = Average number of live young delivered or found in a viable well-grown condition in the uterus at autopsy. $\mathbf{N}=$ Total number of animals in each group.

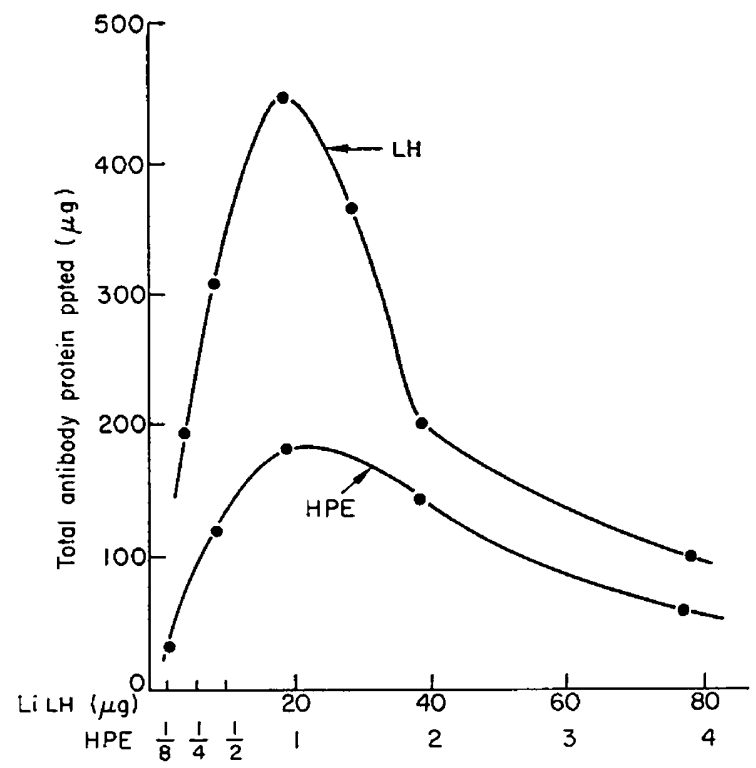

TEXT-FIG. 2. Quantitative precipitin curves with ovine LH antiserum using ovine LH and hamster pituitary extract (HPE) as antigens. A volume of $0.05 \mathrm{ml}$ antiserum was used per tube. Incubation conditions were as described by Moudgal \& Li (1961). Hamster pituitary extract was prepared by homogenizing a pool of pituitaries in saline (four pituitaries/ml), and centrifuging in the cold at $15,000 \mathrm{rev} / \mathrm{min}$. The supernatant was used for the test. 
in 21-day-old mice, according to Igarashi \& McCann (1964). Further, this antiserum could neutralize the FSH activity of hamster pituitary extract as shown by us earlier (Jagannadha Rao \& Moudgal, 1970).

\section{Effect of FSH and LH antisera on implantation in the hamster}

In the hamster, the blastocyst implants on Day 5. Administration of normal rabbit serum (NRS) or FSH antiserum on the morning of Day 4 had no effect on implantation or on the course of pregnancy (Table 1, Groups I and II). Administration of LH antiserum on the morning of Day 3 or Day 4 resulted in inhibition of implantation (Table 1, Groups III and IV), as seen on Day 7. These effects could be reversed by simultaneous administration of $4 \mathrm{mg}$ pro-

TABLE 1

EFFECT OF FSH AND LH ANTISERA ON IMPLANTATION IN HAMSTERS

\begin{tabular}{|c|c|c|c|c|}
\hline Group & $\mathcal{N}$ & Treatment* & $\mathcal{N} I$ & Remarks \\
\hline $\mathbf{I}$ & 10 & NRS on Day 4 & 8 & Normal implantation sites \\
\hline II & 5 & $\begin{array}{l}0.5 \mathrm{ml} \text { FSH antiserum } \\
\text { on Day } 4\end{array}$ & 5 & Normal implantation sites \\
\hline III & 5 & $\begin{array}{l}0.2 \mathrm{ml} \mathrm{LH} \text { antiserum } \\
\text { on Day } 3\end{array}$ & 0 & No implantation \\
\hline IV & 7 & $\begin{array}{l}0.2 \mathrm{ml} \mathrm{LH}_{\text {Lntiserum }} \\
\text { on Day } 4\end{array}$ & 0 & No implantation \\
\hline V & 5 & $\begin{array}{l}0.2 \mathrm{ml} \mathrm{LH} \text { antiserum } \\
\text { on Day } 4 \text { only, and } \\
4 \mathrm{mg} \text { progesterone } \\
\text { with } 1 \mu \text { g oestradiol- } \\
17 \beta \text { on Days } 4 \text { to } 6\end{array}$ & 5 & $\begin{array}{l}\text { Implanted sites secondarily } \\
\text { resorbed on Day } 11 \text { as seen } \\
\text { at autopsy }\end{array}$ \\
\hline VI & 5 & $\begin{array}{l}0.2 \mathrm{ml} \mathrm{LH} \text { antiserum } \\
\text { on Day } 3 \text { only and } \\
0.02 \mu \mathrm{g} \text { oestradiol- } \\
17 \beta \text { on Days } 3 \text { to } 6\end{array}$ & 0 & No implantation \\
\hline
\end{tabular}

$\mathrm{N}=$ Number of animals per group. $\mathrm{NI}=$ Number of animals in which implantation sites were found on Day $7 . \mathrm{NRS}=$ Normal rabbit serum.

* All injections were given at 10.00 hours each day.

gesterone and $1 \mu$ g oestradiol-17 $\beta$ from Days 4 to 6 (Table 1, Group V) but not by a daily dose of $0.02 \mu \mathrm{g}$ oestradiol alone (Table 1, Group VI). Discontinuation of steroid treatment on Day 7 precipitated termination of pregnancy by Day 11 (Table 1, Group V).

\section{Effect of neutralization of endogenous $L H$ on the course of pregnancy}

Administration of a single injection of $\mathrm{LH}$ antiserum any time between Day 6 and Day 11 resulted in profuse vaginal bleeding within 36 to $48 \mathrm{hr}$, followed by resorption of fetuses as seen at autopsy (Pl. 1, Fig. 2, Text-fig. 1). While LH antiserum injection on Days 12 or 13 did not influence the course of gestation, five out of nine animals showed resorption when it was administered on Day 11. The control group receiving normal rabbit serum continued pregnancy to term normally (Table 2, Group I). The effect of deprivation of LH was reflected by a significant reduction in the ovarian weights (Text-fig. 1). 


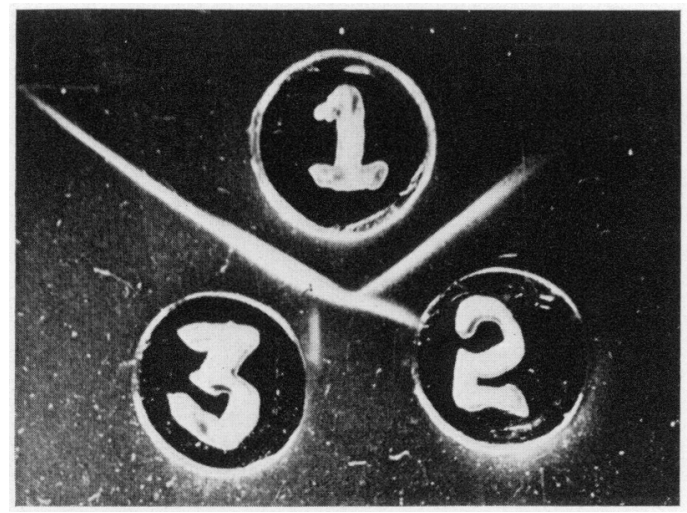

Fig. 1. Agar gel double diffusion test demonstrating the cross reactivity of hamster pituitary LH with ovine LH. Wells contained: (1) rabbit antiserum to I.H, (2) hamster pituitary extract, (3) ovine LH.

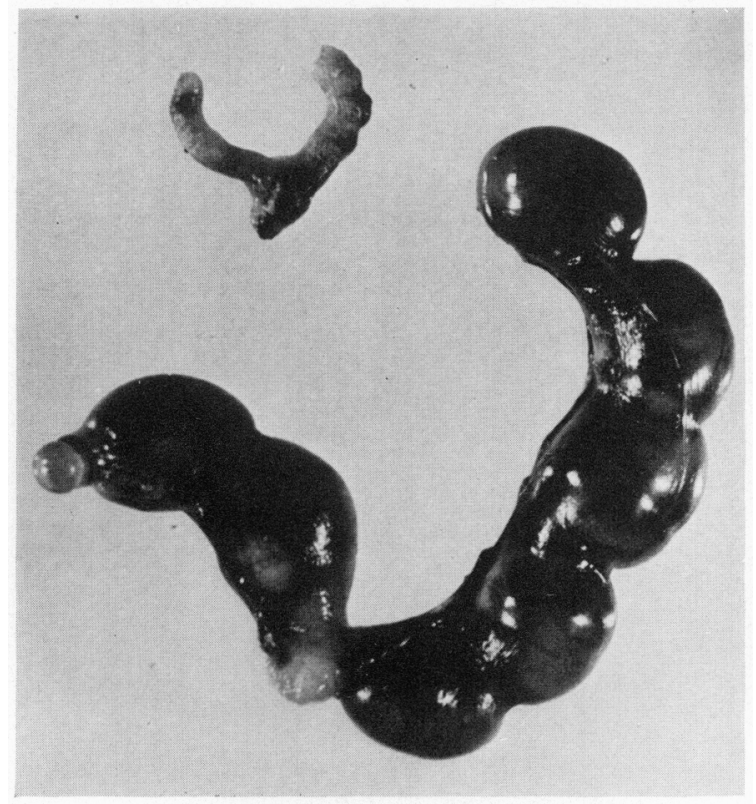

FIG. 2. Photograph showing the condition of the uteri of LII antiscrum and normal rabbit serum (NRS)-treated hamsters at autopsy on Day 14. Upper: I.H antiserum treated on Day 8. Lower: NRS-treated on Day 8. 

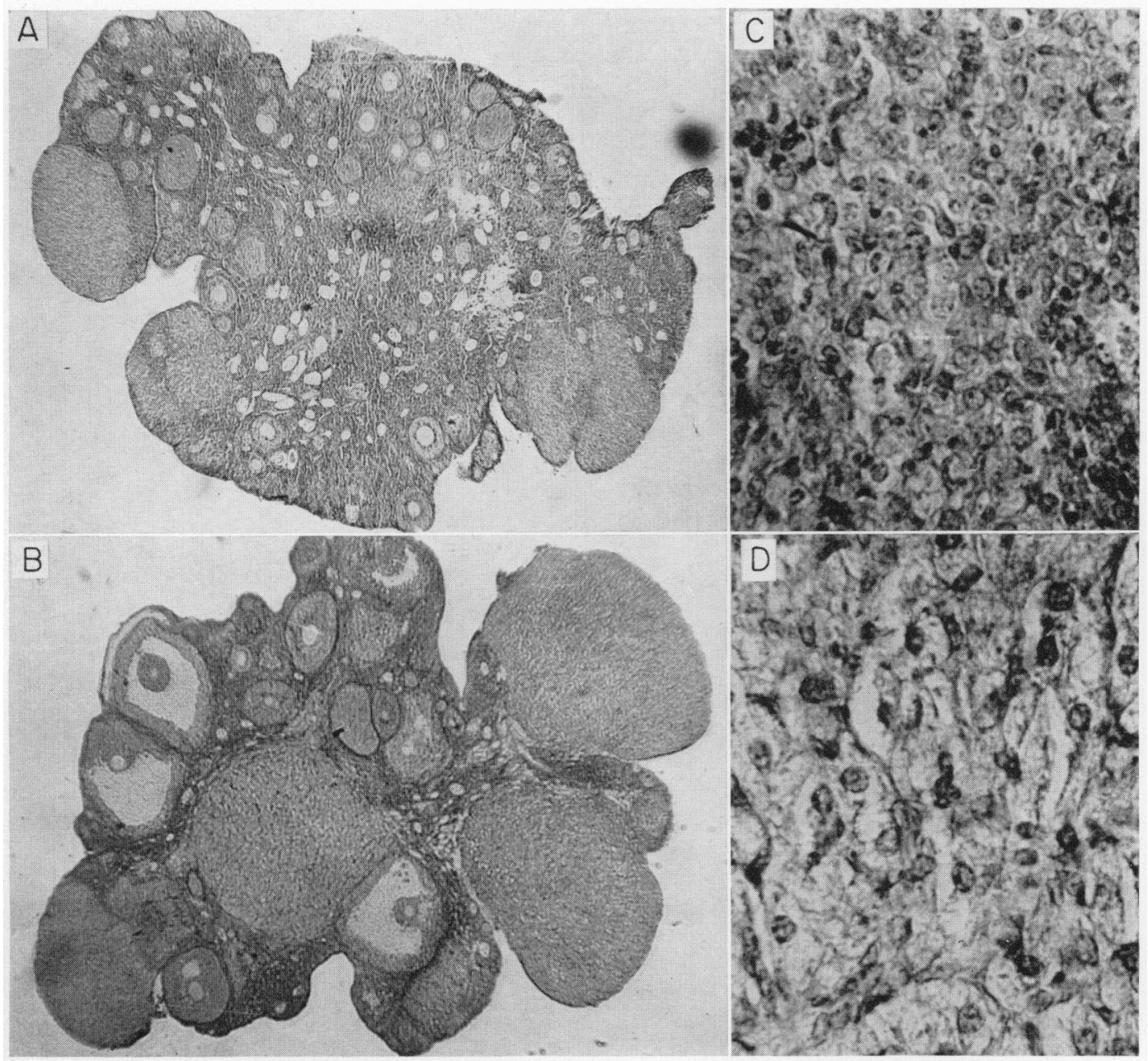

Fif. 3. Histology of ovaries following nomal rabbit serum (NRS) or LH antiserum treatment. A: Ovary of a hamster on Day 12 , treated with the antiserum on Day $8 . \times 8$. B: Ovary of a hamster on Day 12. treated with NRS on Day $8 . \times 8$. (: A corpus luteum from 3A. $\times$ 120. D: A corpus luteum from 3B. $\times 120$. 
PLA'TE: 3

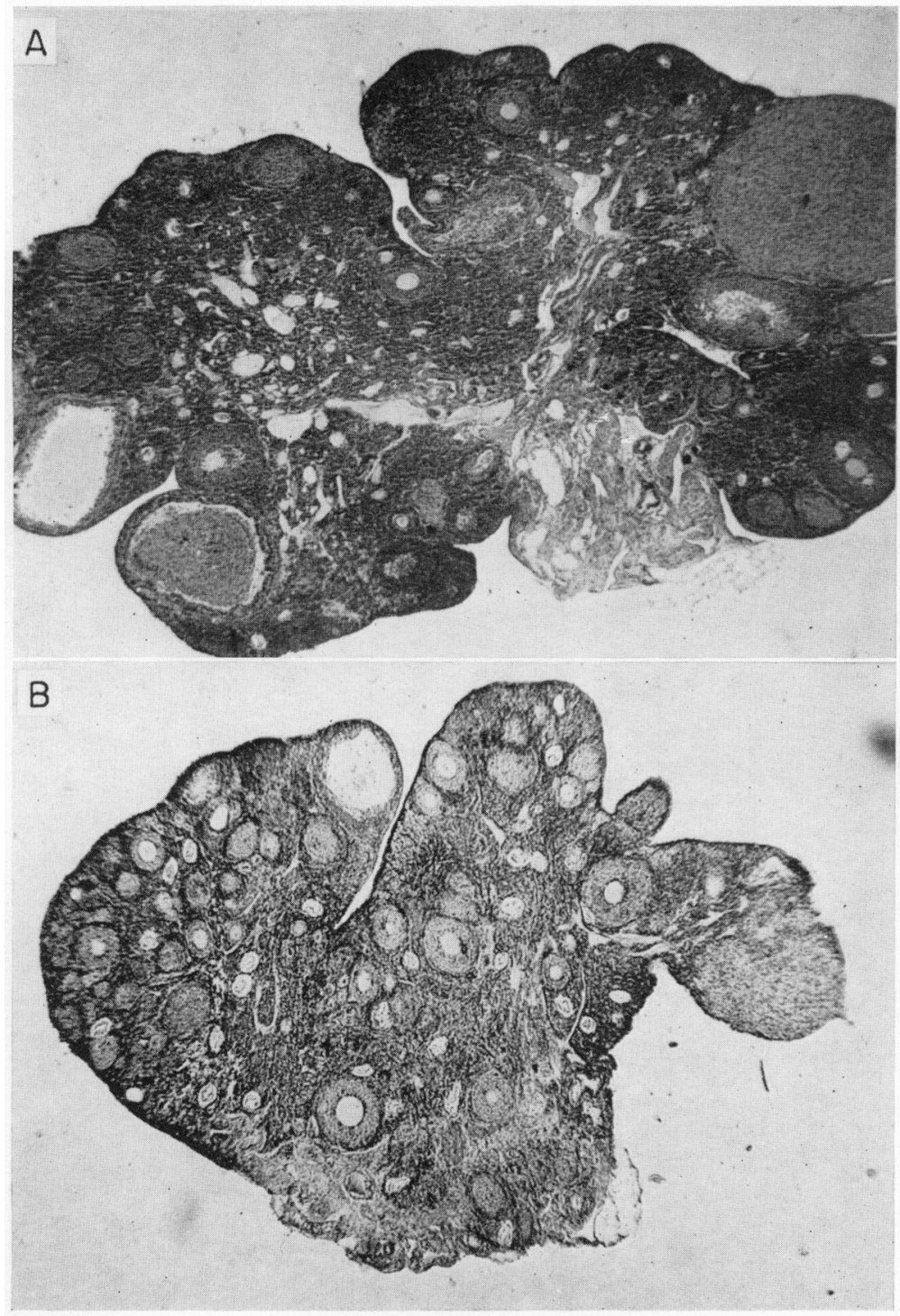

lik, 4. A: Ovary of a hamster on Day 12, treated with Fsh antiserum on Day $8 . \times 8$. B: Ovary of a hamster on Day 12, treated with LH antiserum, $4 \mathrm{mg}$ ovine prolactin and $200 \mu \mathrm{g}$ NiII-Fsir s-6 on Days 8 and $9 . \times 8$. 
TABLE 2

EFFEGT OF LH AND FSH ANTISERA ON THE COURSE OF GESTATION IN THE INTAGT HAMSTER AND THE ABILITY OF GONADOTROPHINS TO REVERSE THIS EFFEGT

\begin{tabular}{|c|c|c|c|c|c|c|}
\hline Group & $\mathcal{N}$ & Treatment & $\begin{array}{l}\text { On } \\
\text { Days }\end{array}$ & Autopsy & $\begin{array}{c}\text { Ovarian } \\
w t(m g) \\
(m e a n \pm S . D)\end{array}$ & Remarks \\
\hline I & 5 & $0.2 \mathrm{ml} \mathrm{NRS}$ & 6 & Day 12 & $44 \cdot 8 \pm 8 \cdot 8$ & $\begin{array}{l}\text { Well-grown } \\
\text { fetuses }\end{array}$ \\
\hline II & 6 & $1.5 \mathrm{ml} \mathrm{FSH}$ antiserum & 8 & Day 14 & $44 \cdot 0 \pm 9 \cdot 8$ & $\begin{array}{l}\text { Well-grown } \\
\text { fetuses }\end{array}$ \\
\hline III & 5 & $0.2 \mathrm{ml} \mathrm{LH}$ antiserum & 9 & Day 16 & $20 \cdot 6 \pm 6 \cdot 2$ & $\begin{array}{l}\text { Bleeding within } \\
48 \mathrm{hr} \text {; resorbed } \\
\text { sites at the time } \\
\text { of autopsy }\end{array}$ \\
\hline IV & 5 & $\begin{array}{l}0.2 \mathrm{ml} \mathrm{LH} \text { antiserum } \\
+200 \mu \mathrm{g} \text { NIH-FSH } \\
+4 \mathrm{mg} \text { prolactin }\end{array}$ & 8,9 & Day 15 & $16 \cdot 7 \pm 2 \cdot 1$ & $\begin{array}{l}\text { Vaginal } \\
\text { bleeding within } \\
48 \mathrm{hr} \text { of treat- } \\
\text { ment and } \\
\text { complete } \\
\text { resorption as } \\
\text { seen at autopsy }\end{array}$ \\
\hline V & 5 & $\begin{array}{l}0.2 \mathrm{ml} \mathrm{LH} \text { antiserum } \\
+100 \mu \mathrm{g} \mathrm{LH}\end{array}$ & 8 & Day 14 & $43 \cdot 0 \pm 5 \cdot 1$ & $\begin{array}{l}\text { Well-grown } \\
\text { living young } \\
\text { in uterus }\end{array}$ \\
\hline
\end{tabular}

$\mathrm{N}=$ Number of animals per Group. $\mathrm{NRS}=$ Normal rabbit serum.

Interestingly, even when the LH antiserum was not effective in terminating gestation (Days 12 and 13), it still brought about a marked reduction in ovarian weights.

On histological examination, it was noted that the LH antiserum-treated hamsters generally had small and regressed corpora lutea (Pl. 2, Fig. A). The follicular development was very poor, there being only a small number of primary follicles and a few Graafian follicles showing poor development. The interstitial tissue was sparse and non-luteinized and was interspersed with primary and secondary follicles. By contrast, the ovaries of the NRS controls showed a large number of well-developed luteal bodies and many normal secondary follicles and Graafian follicles with antra (Pl. 2, Fig. B). Under higher magnification, the luteal cells in the LH antiserum-treated group were smaller in size and showed a low degree of luteinization (Pl. 2, Fig. C) compared to the controls which showed normal, large and well luteinized cells (Pl. 2, Fig. D).

Influence of FSH antiserum on the course of gestation and the effect of supplementing $L H$ antiserum-treated hamsters with gonadotrophins

In view of the observation of Greenwald (1967) that FSH and prolactin constitute the minimal luteotrophic complex of pregnant hamsters, the effect of neutralizing one of the components of this complex by administering a specific FSH antiserum was attempted. The amount of antiserum used was sufficient to neutralize the endogenous FSH activity of the hamster (Jagannadha Rao \& 
Moudgal, 1970). The FSH antiserum treatment, however, had no effect either on the course of gestation or on the ovarian weights of the experimental animals (Table 2, Group II). Histological examination of the ovaries of this group showed a significant reduction in the number of Graafian follicles present without necessarily affecting the ovarian weights (compare Pl. 2, Fig. B with Pl. 3, Fig. A).

Administration of a combination of $200 \mu \mathrm{g} \mathrm{NIH}$ ovine FSH and $4 \mathrm{mg}$ ovine prolactin failed to overcome the effects of LH antiserum, suggesting that the effectiveness of $\mathbf{L H}$ antiserum was not due to any contaminating antibodies to FSH or prolactin (Table 2, Group IV and Pl. 3, Fig. B). On the contrary, the

TABle 3

EFFECT OF STEROID SUPPLEMENTATION ON THE COURSE OF PREGNANCY IN LH ANTISERUM-TREATED HAMSTERS

\begin{tabular}{|c|c|c|c|c|c|c|}
\hline \multirow[b]{2}{*}{ Group } & \multirow[b]{2}{*}{$\mathcal{N}$} & \multicolumn{3}{|c|}{ Treatment on Days } & \multirow{2}{*}{$\begin{array}{l}\text { Ovarian wt } \\
(\mathrm{mg}) \\
\text { (mean } \pm \text { S.D. })\end{array}$} & \multirow[b]{2}{*}{ Results } \\
\hline & & $\begin{array}{c}\text { Antiserum } \\
(0.2 \mathrm{ml})\end{array}$ & $\begin{array}{l}\text { Progester- } \\
\text { one }(5 \mathrm{mg})\end{array}$ & $\begin{array}{c}\text { Oestradiol- } \\
17 \beta(1 \mu \mathrm{g})\end{array}$ & & \\
\hline I & 5 & 7 & 7 & 一 & $19 \cdot 3 \pm 3 \cdot 1$ & $\begin{array}{l}\text { Bleeding seen on } \\
\text { 9th day; } \\
\text { resorbing sites } \\
\text { at autopsy on } \\
\text { 14th day }\end{array}$ \\
\hline II & 5 & 7 & $7,8,9$ & - & $23 \cdot 0 \pm 3 \cdot 7$ & $\begin{array}{l}\text { Out of total } 46 \\
\text { fetuses, } 33 \text { were } \\
\text { living on Day } 14\end{array}$ \\
\hline III & 5 & 8 & $8,9,10$ & $8-10$ & $17 \cdot 5 \pm 1 \cdot 8$ & $\begin{array}{l}\text { Out of total } 36 \\
\text { fetuses, } 33 \text { were } \\
\text { living on Day } 14\end{array}$ \\
\hline IV & 5 & 8 & - & $8-15$ & $16 \cdot 6 \pm 6 \cdot 0$ & $\begin{array}{l}\text { Uterus showed } \\
\text { complete } \\
\text { resorption as } \\
\text { seen on 16th day }\end{array}$ \\
\hline
\end{tabular}

$\mathrm{N}=$ Number of animals per group.

effect of the LH antiserum could be overcome by the simultaneous administration of LH antiserum with sufficient LH to neutralize all the antibody activity (Table 2, Group V). Usually, $0.2 \mathrm{ml} \mathrm{LH}$ antiserum could neutralize the activity of $100 \mu \mathrm{g}$ ovine LH when both were given together.

Effect of steroid supplementation on the course of pregnancy in $L H$ antiserum-treated hamsters

A single dose of antiserum followed by a single dose of progesterone ( $5 \mathrm{mg}$ ) failed to maintain pregnancy (Table 3, Group I). If, however, injection of antiserum was followed by daily supplementation with $5 \mathrm{mg}$ progesterone, $71 \%$ of the fetuses (thirty-three out of forty-six fetuses) were maintained in a viable condition (Table 3, Group II). Daily supplementation with $1 \mu \mathrm{g}$ oestradiol-17 $\beta$ from the day of LH antiserum injection up to term failed to maintain pregnancy (Table 3, Group IV). These animals showed vaginal bleeding followed by resorption, an effect typical of LH antiserum-treated groups. Increasing the 
dose of oestradiol-17 $\beta$ to $2.5 \mu \mathrm{g} /$ day did not prevent resorption. Higher doses of oestradiol were not tried as, at a dose of $5 \mu \mathrm{g} /$ day, this steroid caused resorption even in the absence of the antiserum.

If the LH antiserum-treated animals received $5 \mathrm{mg}$ progesterone and $1 \mu \mathrm{g}$ oestradiol-17 $\beta /$ day for a minimum period of 3 days, pregnancy was maintained (Table 3, Group III), 91\% of the fetuses being viable at autopsy on Day 14 .

Effect of exogenous pituitary gonadotrophins and steroids on second half of pregnancy

Since LH was found to be necessary for the maintenance of pregnancy up to Day 11 in the hamster, and in consideration of our earlier finding that $\mathbf{L H}$

TABLE 4

EFFECT OF ADMINISTERING GONADOTROPHINS AND STEROIDS ON THE GOURSE OF LATE PREGNANCY IN HAMSTERS

\begin{tabular}{|c|c|c|c|c|}
\hline Group & $\mathcal{N}$ & $\begin{array}{l}\text { Daily treatment } \\
\text { from Day } 10 \\
\text { up to delivery }\end{array}$ & $\begin{array}{c}\text { Ovarian wt } \\
(m g) \\
(\text { mean } \pm S . D .)\end{array}$ & Results and observations* \\
\hline I & 6 & $200 \mu \mathrm{g}$ NIH-FSH & $43 \cdot 0 \pm 7 \cdot 7$ & Delivered normally on Day 16 \\
\hline II & 5 & $100 \mu \mathrm{g} \mathrm{LI}-\mathrm{LH}$ & $48 \cdot 2 \pm 6 \cdot 2$ & Delivered normally on Day 16 \\
\hline III & 5 & $1 \mathrm{mg} \mathrm{NIH-prolactin}$ & $42 \cdot 0 \pm 8 \cdot 7$ & Delivered normally on Day 16 \\
\hline IV & 6 & $\begin{array}{l}100 \mu \mathrm{g} \text { NIH-FSH }+ \\
50 \mu \mathrm{g} \mathrm{LI-LH}\end{array}$ & $66 \cdot 0 \pm 8 \cdot 0$ & $\begin{array}{l}\text { Did not deliver on Day } 16 . \\
\text { Parturition started on night } \\
\text { of Day } 17 \text { and completed on } \\
\text { Day } 18 \text {; all young were dead } \\
\text { when delivered; dead fetuses } \\
\text { were also retained in the } \\
\text { uterus }\end{array}$ \\
\hline V & 5 & $8 \mathrm{mg}$ progesterone & $34 \cdot 0 \pm 7 \cdot 6$ & $\begin{array}{l}\text { Did not deliver at all until } \\
\text { progesterone was withdrawn; } \\
\text { fetuses found crushed and } \\
\text { dead at the time of autopsy }\end{array}$ \\
\hline VI & 5 & $\begin{array}{l}1 \mu \mathrm{g} \text { oestradiol- } \\
17 \beta\end{array}$ & $32 \cdot 0 \pm 7 \cdot 0$ & Delivered normally on Day 16 \\
\hline
\end{tabular}

$\mathrm{N}=$ Number of animals per group.

* Normal parturition time in our colony, Day 16 morning $\pm 6 \mathrm{hr}$.

administered after Day 12 postponed parturition in the rat, it seemed of interest to study the effect of LH administration on the course of pregnancy in the hamster. It can be seen from Table 4 that administration of a daily dose of $100 \mu \mathrm{g}$ LH from Day 10 onwards had no effect on parturition (Table 4, Group II). Neither FsH alone (200 $\mu \mathrm{g} /$ day from Day 10 onwards) nor prolactin alone (1 $\mathrm{mg} /$ day from Day 10 onwards) succeeded in postponing parturition (Table 4, Groups I and III). Only a combination of $200 \mu \mathrm{g}$ FsH and a minimum of $50 \mu \mathrm{g} \mathrm{LH} /$ day was able to delay parturition to a significant extent (Table 4, Group IV). The ovarian weight of these animals was higher than those of other groups and the ovaries had many luteal bodies. Of the steroids administered, only progesterone $(8 \mathrm{mg} /$ day from Day 10 onwards) was able to postpone parturition effectively. The animals in this group were not delivered until progesterone was withdrawn. 


\section{DISCUSSION}

Implantation in the hamster occurs on Day 5 (Greenwald 1967) and, though progesterone alone has been shown to be the minimal requirement for nidation in the ovarectomized hamster (Prasad, Orsini \& Meyer, 1960), both oestradiol and progesterone are apparently required for an optimal response (Harper, Prostkoff \& Reeve, 1966).

In the present series of experiments, administration of $\mathrm{LH}$ antiserum on the morning of Day 3 or 4 effectively inhibited implantation, this effect being reversed by supplementation with a combination of progesterone and oestradiol-17 $\beta$. It thus appears that neutralization of $\mathrm{LH}$ during the critical period leads to an inhibition of the steroid synthesis needed for successful implantation. Yoshinaga, Hawkins \& Stocker (1969) have shown the occurrence of an 'oestrogen surge' on Day 4 in the pregnant rat. Our earlier results (Madhwa Raj, Sairam \& Moudgal, 1968) in the same species showed that neutralization of LH between 10.00 and 18.00 hours of Day 4 leads to an inhibition of this surge and consequently to implantation. No information is available on the occurrence of a progesterone or oestrogen surge just before implantation in the hamster.

The results obtained by the selective neutralization of FSH or LH during the pre- and postimplantation periods reveal that the latter is obligatory for successful maintenance of these phases of gestation in the intact hamster. Recent investigations of Greenwald (1967), Grady \& Greenwald (1968) and Choudary \& Greenwald (1967) have shown that the minimal luteotrophic complex of the hamster is composed of FSH and prolactin. Both were essential for the first 12 days to maintain gestation in the hypophysectomized animal. During the latter half of gestation, FSH alone was sufficient to maintain fetuses to term. The inclusion of high doses of $\mathrm{LH}(50$ to $100 \mu \mathrm{g}$ ) in this complex, was found to be deleterious both to the course of gestation and to the maintenance of the structural integrity of the luteal bodies. Low doses of $\mathrm{LH}(1$ to $10 \mu \mathrm{g})$ permitted good ovarian growth and luteal development. The present series of experiments clearly establish that LH is an essential constituent of the luteotrophic complex, and that neutralization of endogenous LH as such leads to the termination of gestation. Following antiserum treatment, the corpora lutea invariably degenerated by the time of autopsy. The labelled hormone-binding experiments emphasize the specificity of the antiserum effects, and the fact that, of the two hormone supplements tried, i.e. FsH-prolactin combination or $\mathbf{L H}$, only the latter could neutralize the effects of the antiserum, overrules the possibility of any contaminating antibodies being present in the LH antiserum. The observation that a single injection of $\mathrm{LH}$ antiserum had to be followed by a continuous daily administration of progesterone and oestrogen for the successful maintenance of gestation stresses the importance of $\mathrm{LH}$ in maintaining optimal steroidogenesis.

The present results also show that neutralization of FSH activity had apparently no deleterious effect on the implanted blastocysts, though they do not, thereby, exclude a rôle for this hormone in the maintenance of normal gestation. Greenwald (1964) has observed a good population of follicles in various stages 
of development in the ovary during the entire length of gestation in the hamster. Though no quantitative studies on the follicular population in the ovaries of various groups were undertaken in the present study, it was observed that FSH antiserum treatment did bring about a decrease in the number of Graafian follicles. Greenwald (1967) observed that the corpora lutea of pregnant hamsters were very sensitive to the dose of $\mathrm{LH}$ administered in saline, low doses promoting luteal maintenance, while high doses are deleterious. Based on experience in the rat, where LH given in a delay vehicle has been shown to assist in maintaining gestation in the hypophysectomized animal (Macdonald, Armstrong \& Greep, 1967; Moudgal, 1969), it might be that even in the hamster LH has to be given in a delay vehicle for it to be efficacious.

The steroidogenic ability of $\mathbf{L H}$ both in vivo and in vitro has been widely documented in a variety of species. The studies in vitro using ovarian slices from rat (Major, Armstrong \& Greep, 1967), pig (Cook, Kaltenbach, Norton \& Nalbandov, 1967), cattle (Mason \& Savard, 1964) and human (Rice, Hammerstein \& Savard, 1964) have demonstrated unequivocally the ability of LH to stimulate progesterone synthesis. Recent work of Moudgal \& Behrman (1970) has shown that injection of $\mathrm{LH}$ antiserum to pregnant rats brings about a reduction of progesterone secretion in ovarian effluents by as much as $80 \%$ in $24 \mathrm{hr}$. Such studies on the effect of individual gonadotrophins and gonadotrophin antisera on steroidogenesis in hamster ovaries in vivo and in vitro have yet to be carried out. The ovarian progesterone levels have been shown by Lukaszewska \& Greenwald (1970) to be maximal during dioestrus (Day 2 of the cycle). These investigators further showed that, following implantation, the progesterone content of the corpus luteum increased gradually, reaching peak values between Days 10 to 13. Luteal progesterone content and concentration, as well as peripheral plasma progesterone concentration, declined to low levels by Day 16. Thus, there appears to be a direct correlation between our observation that the hamster corpus luteum is sensitive to the lack of LH till Day 11 and the observation of Greenwald that the progesterone concentration of the corpus luteum reaches a peak by this time.

Administration of progesterone to the hamster during the second half of gestation results in the postponement of parturition. When FSH, LH and prolactin were tested for their ability to produce high titres of progesterone and a delay in parturition, none of them was effective individually but a combination of $200 \mu \mathrm{g} \mathrm{NIH-FSH}$ and a minimum of $50 \mu \mathrm{g} \mathrm{Li}-\mathrm{LH}$ did bring about a postponement in parturition. This effect could probably be attributed to the increased amount of progesterone synthesized by the large number of new luteal bodies formed as a consequence of gonadotrophin treatment. The combined FsH and LH treatment in the hamster was started from Day 10, by which time, according to Lukaszewska \& Greenwald (1970), the corpora lutea would be synthesizing progesterone at their maximum capacity. In the hamster, therefore, once the corpus luteum of pregnancy has reached its peak capacity, it may not be possible to overstimulate it with exogenous gonadotrophins. In our earlier observation on the pregnant rat (Madhwa Raj \& Moudgal, 1970), administration of LH alone on Day 12 of pregnancy did bring about a postponement in parturition, without necessarily increasing the number of luteal bodies. The 
hamster, like the rabbit, is dependent on hypophysial support for the maintenance of normal gestation during its entire length. The pituitary trophic hormone, $\mathrm{LH}$, which is normally necessary for implantation and the maintenance of early pregnancy, is dispensed with in the hamster, however, after Day 11. On the basis of an earlier observation (Moudgal, Madhwa Raj, Jagannadha Rao \& Sairam, 1969) that LH antiserum is not effective in terminating gestation in the pregnant rat after Day 12 and that the steroid-synthesizing ability of the pregnant rat ovary reaches a peak by Day 12 (Wiest, 1970), we suggested that there could be a correlation between the ineffectiveness of the antiserum and the reduction in the steroid-synthesizing ability of the ovary (Madhwa Raj \& Moudgal, 1970). It was suggested that high titres of steroids produced at midgestation may be acting as an external feed-back to reduce pituitary LH secretion in the second half of pregnancy. In this respect, the hamster seems to resemble the rat.

\section{ACKNOWLEDGMENTS}

The authors are grateful to the Ford Foundation, New York, and the Ministry of Health and Family Planning, Government of India, for financial help, and to Dr B. R. Srinath, Mr R. Srinivasan and Mr B. Shanmugavelu for skilled technical help.

The ovine NIH-FSH s- 6, s-7 and s-8, NIH-LH s-12 and s-13 and ovine prolactin (мH) used in this study were gifts of the endocrine study section, National Institute of Health, U.S.A. The highly purified preparation of ovine LH, prolactin and ovine FSH (forty-five times as active as NIH-FSH S-1) used here were gifts from Professor C. H. Li and Dr H. Papkoff, Hormone Research Laboratories, University of California Medical Center, San Francisco. Oestradiol-17 $\beta$ and progesterone were purchased from Sigma Chemical Company, U.S.A.

\section{REFERENCES}

Ghoudary, J. B. \& Greenwald, G. S. (1967) Effect of an ectopic pituitary gland on luteal maintenance in the hamster. Endocrinology, 81, 542.

Cook, B., Kaltenbach, C. C., Norton, H. W. \& Nalbandov, A. V. (1967) Synthesis of progesterone in vitro by porcine corpora lutea. Endocrinology, 81, 573 .

Grady, K. L. \& GreENWALd, G. S. (1968) Gonadotropic induction of pseudopregnancy in the cyclic hamster. Endocrinology, 83, 1173.

Greenwald, G. S. (1964) Follicular development in the pregnant hamster. Anat. Rec. 148, 605.

GreENwALd, G. S. (1967) Luteotropic complex of the hamster. Endocrinology, 80, 118.

Harper, M. J. K., Prostkoff, B. T. \& Reeve, R. J. (1966). Implantation and embryonic development in the ovariectomized hamster. Acta endocr., Copenh. 52, 465.

Igarashi, M. \& MCCANn, S. M. (1964) A new sensitive bio-assay for follicle-stimulating hormone (FSH). Endocrinology, 74, 440.

Jagannadha Rao., A., Madhwa RaJ, H. G. \& Moudgal, N. R. (1970) Need of luteinizing hormone for maintaining early pregnancy in the golden hamster (Mesocricetus auratus). F. Reprod. Fert. 23, 353.

Jagannadha Rao, A. \& Moudgal, N. R. (1970) An immunochemical study of ovine pituitary follicle stimulating hormone. Archs Biochem. Biophys. 138, 189.

Lukaszewska, J. H. \& Greenwald, G. S. (1970) Progesterone levels in the cyclic and pregnancy hamster. Endocrinology, 86, 1.

Macdonald, G. J., Armstrong, D. T. \& Greep, R. O. (1967) Initiation of blastocyst implantation by luteinizing hormone. Endocrinology, 80, 172. 
Madhwa Raj, H. G. \& Moudgal, N. R. (1970) Hormonal control of gestation in the intact rat. Endocrinology, 86, 874.

Madhwa RaJ, H. G., Sairam, M. R. \& Moudgal, N. R. (1968) Involvement of luteinizing hormone in the implantation process of the rat. F. Reprod. Fert. 17, 335.

Major, P. W., Armstrong, D. T. \& Greep, R. O. (1967) Effects of luteinizing hormone in vivo and in vitro on cholesterol conversion to progestins in the rat corpus luteum tissue. Endocrinology, $81,19$.

Mason, N. R. \& SAVARD, K. (1964) Specificity of gonadotropin stimulation of progesterone synthesis in bovine corpus luteum in vitro. Endocrinology, 74, 664 .

Moudgal, N. R. (1969) The effect of luteizing hormone administration on the course of early pregnancy in hypophysectomized pregnant rats. Nature, Lond. 222, 286.

Moudgal, N. R. \& BeHRman, H. R. (1970) The effect of LH antiserum (LH A/S) on ovarian progestin output. Proc. 3rd Meet. Soc. Study Reprod. Abstract, p. 25.

Moudgal, N. R. \& LI, C. H. (1961) An immunochemical study of sheep pituitary interstitial cell stimulating hormone. Archs Biochem. Biophys. 95, 93.

Moudgal, N. R., Madhwa Raj, H. G., Jagannadha Rao, A. \& Sairam, M. R. (1969) Need of luteinizing hormone for maintaining early pregnancy in rat. Indian fnl exp. Biol. 7, 45.

Prasad, M. R. N., Orsini, M. W. \& MEYer, R. K. (1960) Nidation in progesterone treated oestrogen deficient hamster, Mesocricetus auratus. Proc. Soc. exp. Biol. Med. 104, 48.

Rice, B. F., Hammerstein, J. \& Savard, K. (1964) Steroid hormone formation in the human ovary. II. Action of gonadotropins in vitro in the corpus luteum. F. clin. Endocr. Metab. 24, 606.

WIEst, W. G. (1970) Progesterone and 20 $\alpha$-hydroxypregn-4-en-3-one in plasma, ovaries and uteri during pregnancy in the rat. Endocrinology, 87, 43.

Yoshinaga, K., Hawkins, R. A. \& StockeR, J. F. (1969) Estrogen secretion by the rat ovary in vivo during the estrous cycle and pregnancy. Endocrinology, 85, 103. 